\title{
The Relationship between Gut Peptides (Polypeptide YY and Ghrelin) Serum Concentration and Metabolic Syndrome Components in Egyptian Male Patients
}

\author{
EL-SAEID M.E. EL-BAWAB, M.D.*; ISLAM G.M. RABIA, M.D.* and ASHRAF M. ALKABER, M.D.** \\ The Departments of Medical Biochemistry* and Internal Medicine**, Faculty of Medicine, Al-Azhar University (Assuit), Egypt
}

\begin{abstract}
Background: Over the past two decades, a striking increase in the number of people with the metabolic syndrome worldwide has taken place. This increase is associated with the global epidemic of obesity and diabetes. With the elevated risk not only of diabetes but also of cardiovascular disease from the metabolic syndrome, there is urgent need for strategies to prevent the emerging global epidemic. The metabolic syndrome is a master of disguise since it can present in various ways according to the different components that constitute the syndrome.
\end{abstract}

Aim of Study: This study was to estimate the fasting plasma levels of PYY and ghrelin in lean versus metabolic syndrome overweighed patients.

Patients and Methods: This case-control study included 20 lean (normal weight) healthy control subjects and 80 MetS subjects 20 with (abdominal obesity, high blood pressure, high blood sugar), 20 with (abdominal obesity, high blood sugar high serum triglycerides), 20 [abdominal obesity, high blood sugar low high-density lipoprotein (HDL) levels] and 20 with (high blood pressure, abdominal obesity, high serum triglycerides) the age range of the participants was 20-50 years and the participants' anthropometric characteristics were measured.

Results: Total cholesterol (TC) and triglycerides (TG), Insulin, HbA1C and HOMA-IR in patients with MetS were significantly higher, while HDL-C, Ghrelin and PYY were significantly lower in MetS patients.

Conclusion: The current study revealed the possible role of several GI-hormones in the pathogenesis of obesityassociated diseases and MetS. Additional works are needed to elucidate the possible underlying mechanisms and clarify several controversies in this issue.

Key Words: Metabolic Syndrome - PYY - Ghrelin - Insulin - HbAl C-HOMA-IR.

\section{Introduction}

METABOLICSYNDROME (MetS) is a complex disease characterized by raised blood pressure,

Correspondence to: Dr. Islam G.M. Rabia,

E-Mail: eslamgamal@gmail.com central obesity, dyslipidemia and hyperglycemia andit is related to increased risk of cardiovascular mortality, stroke, diabetes mellitus type 2 , and even death [1]. The prevalence of MetS is increasing with body mass index (BMI) and age [2] .

Several prior studies showed that MetS is associated with a 3-to-4.3-fold increase in mortality from cardiovascular disease (CVD) and subjects with MetS were 3.5 to 5 times more likely to develop type 2 diabetes [3,4]. Peptide YY (PYY), another satiety GI hormone, exists in two forms of PYY3-36 and PYY1-36 [5]. The circulating PYY3-36 as the predominant form is a major endocrine mediator of satiation and reduces body weight and its deficiency is a potent inducer of obesity [6]. Its effects on inhibition of food intake mostly occur through its high affinity to presynaptic inhibitory neurons [5].

Ghrelin, a peptide of 28 amino acid polypeptide, was first identified by Kojima et al. [7]. In rat and human stomachs as an endogenous ligand of growth hormone secretagogue receptor [7]. In addition to the growth hormone secretion, ghrelin has been reported to be implicated in other processes such as food intake, insulin release, gastric acid secretion and body weight gain [8] .

In contrast to previously mentioned satiation GI peptides (PYY and CCK), ghrelin increases GI motility and decreases insulin secretion. Ghrelin concentration reduces in response to high doses of PYY3-36 in the pre-meal period [9]. There are limited studies reporting the possible role of GI hormones in the MetS. In the study by ZwirskaKorczala [5], in comparison of basal concentrations of CCK, PYY, ghrelin and gastrin ina relatively low sample size of healthy lean $(n=8)$, obese $(n=12)$ and morbid obese $(n=18)$ patients with MetS, 
reported higher CCK and PYY concentrations in lean controls compared with obese patients with MetS while ghrel in concentrations were higher in morbid obese patients with MetS than in obese patients with MetS $(p<0.05)$.

No association of these hormones with MetS in gredients was reported. Inseveral other studies the possible role of different gene variants of PYY or ghrelin as potent predictor of MetS and its components in different ethnic populations had also been reported $[\mathbf{1 0 , 1 1}]$. The above introduction eluci dates the possible role of GI hormones in association with MetS and its in gredients. However, according to our review of literature, no study was available to assess the possible relationship of these GI hormones with MetS components in obese subjects.

Aim of the study:

Was to estimate the fasting plasma levels of PYY and ghrelin in lean versus metabolic syndrome overweighed patients.

\section{Patients and Methods}

The present case-control study was carried out between August and October of 2019, in Asssuit Branch, Faculty of Medicine Al-Azhar University, Egypt. The MetS was diagnosed according to guidelines from the National Cholesterol Education Program's Adult Treatment Panel III (NCEP-ATP III) [12]. MetS can be diagnosed when patients have $>3$ of 5 following criteria: Increased level of triglycerides (TG) $(>150 \mathrm{mg} / \mathrm{dL})$, waist circumference (WC) $>88 \mathrm{~cm}$ in women and $>102 \mathrm{~cm}$ in men, low serum high density lipoprotein cholesterol $(\mathrm{HDL}-\mathrm{C})(<40 \mathrm{mg} / \mathrm{dL}$ for men and $<50 \mathrm{mg} / \mathrm{dL}$ for women), diastolic blood pressure (DBP $>85 \mathrm{mmHg}$ ) or systolic blood pressure $(\mathrm{SBP})>130 \mathrm{mmHg}$ and fasting blood glucose $(\mathrm{FBG})>100 \mathrm{mg} / \mathrm{dL}$.

Therefore, groups were classified into:

- Group I ( $\mathrm{n}=20)$ : Lean (normal weight) healthy control subjects [body mass index range 18.5$\left.24.9 \mathrm{~kg} / \mathrm{m}^{2}\right][13]$

- Group II ( $\mathrm{n}=80)$ : Metabolic syndrome overweighed patients, who were sub-classified according Kaur [14] into:

i- Group IIa ( $n=20)$ : Abdominal obesity, high blood pressure and high blood sugar.

ii- Group IIb ( $n=20)$ : Abdominal obesity, high blood sugar and high serum triglycerides.

iii- Group IIc ( $n=20)$ : Abdominal obesity, high blood sugar and low high-density lipoprotein (HDL) levels. iv- Group IId ( $\mathrm{n}=20)$ : High blood pressure, abdominal obesity and high serum triglycerides.

\section{Inclusion criteria:}

Having BMI $>30 \mathrm{~kg} / \mathrm{m}^{2}$ and being aged between 20-50 years. We excluded the patients with the history of kidney or cardiovascular complications, cancer, ather osclerosis, recent surgery and those treated by anti-depressive, diuretics, glucocorticoids, anti-hypertensive, hypoglycemic and/or hypolipidemic drugs in the past three months.

\section{Exclusion criteria:}

Diet for losing weight, being pregnant or lactating and menopause in the previous 3 months.

Participants were informed about the protocol and gave their written consent before initiation of the study. The project was approved by the ethical committee of Al-Azhar University of Medical Science. The study was conducted in accordance with the Declaration of Helsinki.

Assessments of anthropometric, blood pressure and appetite:

Anthr opometric variables such as BMI, WC, height and weight were measured by trained interviewers. Weight was assessed by using a digital scale with $0.1-\mathrm{kg}$ precision and the height was assessed by a stadiometer with a precision of $0.5 \mathrm{~cm}$. WC was assessed in the standing position at the level midway between the anterior iliac crest and the lower border of the rib. BMI was assessed as weight $(\mathrm{kg}) /$ height $\left(\mathrm{m}^{2}\right)$. Blood pressure was recorded by a standard mercury sphygmomanometer twice after 10 minutes of rest. The mean of the two readings was assigned as DBP and SBP measurement.

In this study, appetite profile was assessed by anchored 100-mm visual analogue scales (VAS). Participants were asked to respond to 10 questions relating to hunger, appetite, fullness, thirst, satiety, desire to eat and prospective food intake by VAS for each question.

\section{Biochemical assessments:}

After 12-14 hours fasting, venous blood sample was collected from each individual. The plasma and serum samples were separated and stored at $-70^{\circ} \mathrm{C}$ till further use. Scrum PYY, CCK and ghrelin levels were measured by commercial active ELISA kits (Hangzhou East Biopharm Co, LTD, USA). The inter-assay and intra-assay coefficients of variation $(\mathrm{CV})$ for PYY, and ghrelin were $<12 \%$ and $<10 \%$ respectively. Serum insulin was assessed by Diametra assay ELISA kit with the inter-assay 
and intra-assay $\mathrm{CV}$ of $<10 \%$ and $<5 \%$, respectively. Serum Ox-LDL was assessed by Bioassay Technology Laboratory ELISA kit with the inter-assay and intra-assay CV of $<10 \%$ and $<8 \%$, respectively. Concentrations of serum lipids (TC, TG and HDLC) were assessed by enzymatic methods and serum LDL-C levels were estimated. All of the biochemical analyses were carried out blind by a trained lab assistant.

\section{Statistical analysis:}

Data were fed to the computer using IBM SPSS software package version 24.0. Quantitative data were described using mean and standard deviation for normally distributed data. For normally distributed data, comparison between two independent population were done using independent $t$-test while more than two population were analyzed Ftest (ANOVA) to be used. Significance test results are quoted as two-tailed probabilities. Significance of the obtained results was judged at the 5\% level.

\section{Results}

Table (1): Comparison between the different studied groups regarding age.

\begin{tabular}{llllll}
\hline $\begin{array}{l}\text { Age } \\
\text { (years) }\end{array}$ & $\begin{array}{l}\text { Group I } \\
\text { "n=20" }\end{array}$ & $\begin{array}{c}\text { Group IIa } \\
\text { "n=20" }\end{array}$ & $\begin{array}{c}\text { Group IIb } \\
\text { "n=20" }\end{array}$ & $\begin{array}{l}\text { Group IIc } \\
\text { "n=20" }\end{array}$ & $\begin{array}{c}\text { Group IId } \\
\text { "n=20" }\end{array}$ \\
\hline Range & $35.0-54.0$ & $36.0-54.0$ & $37.0-55.0$ & $35.0-55.0$ & $35.0-55.0$ \\
Mean & 44.85 & 44.45 & 47.60 & 43.30 & 47.10 \\
S.D. & 5.18 & 5.67 & 5.36 & 5.50 & 6.39 \\
ANOVA & & & 2.097 & & \\
$p$-value & & & 0.087 N.S. & & \\
$p_{1}$ & & 0.823 N.S & 0.126 & 0.387 & 0.210 \\
$p_{2}$ & & 0.08 & 0.520 & 0.140 \\
$p_{3}$ & & & & 0.062 & 0.852 \\
$p_{4}$ & & & & & 0.071 \\
\hline
\end{tabular}

The difference in ages (mean $\pm \mathrm{SD}$ ) between controls and the four diseased groups was in significant (Anova $=2.097$ and $p$-value $=0.087$ ), also insignificant difference between any diseased group and other diseased groups (Table 1).

Table (2): Comparison between the different studied groups regarding BMI.

\begin{tabular}{llllll}
\hline BMI & $\begin{array}{c}\text { Group I } \\
\text { "n=20" }\end{array}$ & $\begin{array}{c}\text { Group IIa } \\
\text { "n=20" }\end{array}$ & $\begin{array}{c}\text { Group IIb } \\
\text { "n=20" }\end{array}$ & $\begin{array}{c}\text { Group IIc } \\
\text { "n=20" }\end{array}$ & $\begin{array}{c}\text { Group IId } \\
\text { "n=20" }\end{array}$ \\
\hline Range & $18.50-$ & $25.50-$ & $25.00-$ & $25.30-$ & $25.30-$ \\
& 24.30 & 29.90 & 29.60 & 29.90 & 29.90 \\
Mean & 21.83 & 28.11 & 26.95 & 28.03 & 27.62 \\
S.D. & 1.87 & 1.35 & 1.62 & 1.30 & 1.51 \\
ANOVA & & & 59.179 & & \\
$p_{\text {-value }}$ & & & $0.001^{*}$ & & \\
$p_{1}$ & & $0.001 *$ & $0.003^{*}$ & $0.001^{*}$ & $0.001^{*}$ \\
$p_{2}$ & & & 0.08 & 0.652 & 0.103 \\
$p_{3}$ & & & & 0.086 & 0.211 \\
$p_{4}$ & & & & & 0.107 \\
\hline
\end{tabular}

The difference in BMI (mean $\pm \mathrm{SD}$ ) between controls and the four diseased groups was significant (Anova=59.179 and $p$-value $0.001 *$ ), but insignificant difference between any diseased group and other diseased groups (Table 2).

Table (3): Comparison between the different studied groups regarding waist circumference (WC).

\begin{tabular}{llllll}
\hline WC & $\begin{array}{c}\text { Group I } \\
\text { "n=20" }\end{array}$ & $\begin{array}{c}\text { Group IIa } \\
\text { "n=20" }\end{array}$ & $\begin{array}{c}\text { Group IIb } \\
\text { "n=20" }\end{array}$ & $\begin{array}{c}\text { Group IIc } \\
\text { "n=20" }\end{array}$ & $\begin{array}{c}\text { Group IId } \\
\text { "n=20" }\end{array}$ \\
\hline Range & $94.00-$ & $115.00-$ & $116.00-$ & $118.00-$ & $116.00-$ \\
& 102.0 & 142.0 & 142.0 & 142.0 & 142.0 \\
Mean & 98.80 & 127.80 & 128.70 & 131.25 & 129.00 \\
S.D. & 2.75 & 8.50 & 9.14 & 7.73 & 8.77 \\
ANOVA & & & & & \\
$p$-value & & & $0.001 *$ & & \\
$p_{1}$ & & & & & \\
$p_{2}$ & & & $0.001 *$ & $0.001 *$ & $0.001 *$ \\
$p_{3}$ & & & 0.211 & 0.103 & 0.162 \\
$p_{4}$ & & & & 0.31 & 0.562 \\
\hline
\end{tabular}

The difference in waist circumference (mean \pm SD) between controls and the four diseased groups was significant (Anova=62.072 and $p$ value $0.001 *$ ), but insignificant difference between any diseased group and other diseased groups (Table 3).

Table (4): Comparison between the different studied groups regarding Fasting insulin (mIU/L).

\begin{tabular}{|c|c|c|c|c|c|}
\hline $\begin{array}{l}\text { Fasting } \\
\text { insulin } \\
(\mathrm{mIU} / \mathrm{L})\end{array}$ & $\begin{array}{l}\text { Group I } \\
\text { "n=20" }\end{array}$ & $\begin{array}{c}\text { Group IIa } \\
\text { "n=20" }\end{array}$ & $\underset{\text { Group IIb }}{\text { Ge20" }}$ & $\underset{\text { Group IIc }}{\text { n=20" }}$ & $\begin{array}{l}\text { Group IId } \\
\text { "n=20" }\end{array}$ \\
\hline Range & $\begin{array}{l}11.10- \\
14.50\end{array}$ & $\begin{array}{l}20.10- \\
29.70\end{array}$ & $\begin{array}{l}20.60- \\
29.70\end{array}$ & $\begin{array}{l}20.80- \\
29.60\end{array}$ & $\begin{array}{l}20.00- \\
29.60\end{array}$ \\
\hline Mean & 12.74 & 25.72 & 25.33 & 25.76 & 24.81 \\
\hline S.D. & 1.15 & 3.26 & 3.19 & 2.62 & 3.38 \\
\hline ANOVA & & & 79.790 & & \\
\hline$p$-value & & & $0.001^{*}$ & & \\
\hline$p_{1}$ & & $0.001^{*}$ & $0.001^{*}$ & $0.001 *$ & $0.001^{*}$ \\
\hline$p_{2}$ & & & 0.682 N.S & 0.568 N.S & 0.425 \\
\hline$p_{3}$ & & & & 0.78 N.S & 0.81 \\
\hline$p_{4}$ & & & & & 0.462 \\
\hline
\end{tabular}

The difference in fasting insulin (mIU/L) (mean \pm SD) between controls and the four diseased groups was significant $($ Anova $=79.790 p$-value $=$ $0.001 *)$, but insignificant difference between other diseased groups (Table 4). 
Table (5): Comparison between the different studied groups regarding HOMA IR.

\begin{tabular}{|c|c|c|c|c|c|}
\hline $\begin{array}{l}\text { HOMA } \\
\text { IR }\end{array}$ & $\begin{array}{l}\text { Group I } \\
\text { " }=20 "\end{array}$ & $\begin{array}{c}\text { Group IIa } \\
\text { "n=20" }\end{array}$ & $\begin{array}{l}\text { Group IIb } \\
\text { "n=20" }\end{array}$ & $\begin{array}{l}\text { Group IIc } \\
\text { "n=20" }\end{array}$ & $\begin{array}{l}\text { Group IId } \\
\text { "n=20" }\end{array}$ \\
\hline Range & $2.70-3.50$ & $5.70-7.70$ & $5.40-7.50$ & $5.40-7.70$ & $5.40-7.70$ \\
\hline Mean & 3.04 & 6.92 & 6.47 & 6.70 & 6.76 \\
\hline S.D. & 0.28 & 0.64 & 0.68 & 0.74 & 0.71 \\
\hline ANOVA & & \multicolumn{4}{|c|}{79.790} \\
\hline$p$-value & & \multicolumn{4}{|c|}{$0.001 *$} \\
\hline$p_{1}$ & & $0.001 *$ & $0.001^{*}$ & $0.001 *$ & $0.001 *$ \\
\hline$p_{2}$ & & & 0.120 & 0.107 & 0.112 \\
\hline$p_{3}$ & & & & 0.301 & 0.214 \\
\hline$p_{4}$ & & & & & 0.82 \\
\hline
\end{tabular}

The difference in HOMA IR (mean $\pm \mathrm{SD}$ ) between controls and the four diseased groups was significant (Anova $=135.354 p$-value $=0.001 *)$, but insignificant difference between other diseased groups (Table 5).

Table (6): Comparison between the different studied groups regarding $\mathrm{HbA} 1 \mathrm{c}$.

\begin{tabular}{|c|c|c|c|c|c|}
\hline $\mathrm{HbA} 1 \mathrm{c}$ & $\begin{array}{l}\text { Group I } \\
\text { "n=20" }\end{array}$ & $\begin{array}{l}\text { Group IIa } \\
\text { "n=20" }\end{array}$ & $\begin{array}{l}\text { Group IIb } \\
\text { "n=20" }\end{array}$ & $\begin{array}{l}\text { Group IIc } \\
\text { "n=20" }\end{array}$ & $\begin{array}{l}\text { Group IId } \\
\text { "n=20" }\end{array}$ \\
\hline Range & $4.50-5.50$ & $7.00-8.50$ & $6.80-8.50$ & $6.80-8.50$ & $6.80-8.50$ \\
\hline Mean & 4.92 & 7.67 & 7.73 & 7.67 & 7.59 \\
\hline S.D. & 0.31 & 0.54 & 0.56 & 0.51 & 0.52 \\
\hline ANOVA & & \multicolumn{4}{|c|}{122.355} \\
\hline$p$-value & & \multicolumn{4}{|c|}{$0.001 *$} \\
\hline$p_{1}$ & & $0.001 *$ & $0.001 *$ & $0.001^{*}$ & $0.001^{*}$ \\
\hline$p_{2}$ & & & 0.231 & 0.889 & 0.421 \\
\hline$p_{3}$ & & & & 0.521 & 0.101 \\
\hline$p_{4}$ & & & & & 0.36 \\
\hline
\end{tabular}

The difference in $\mathrm{HbA} 1 \mathrm{c}$ (mean $\pm \mathrm{SD}$ ) between controls and the the four diseased groups was significant $($ Anova $=122.355, p$-value $=0.001)$ but insignificant difference between other diseased groups (Table 6).

Table (7): Comparison between the different studied groups regarding Serum triglyceride.

\begin{tabular}{|c|c|c|c|c|c|}
\hline $\begin{array}{l}\text { Serum } \\
\text { triglyceride }\end{array}$ & $\begin{array}{l}\text { Group I } \\
\text { "n=20" }\end{array}$ & $\begin{array}{l}\text { Group IIa } \\
\text { "n=20" }\end{array}$ & Group IIb & $\begin{array}{l}\text { Group IIc } \\
" \mathrm{n}=20 "\end{array}$ & $\begin{array}{l}\text { Group IId } \\
\text { "n=20" }\end{array}$ \\
\hline Range & $\begin{array}{l}106.0- \\
145.0\end{array}$ & $\begin{array}{l}107.0- \\
140.0\end{array}$ & $\begin{array}{l}203.0- \\
287.0\end{array}$ & $\begin{array}{l}105.0- \\
144.0\end{array}$ & $\begin{array}{l}193.0- \\
289.0\end{array}$ \\
\hline Mean & 126.35 & 123.15 & 237.45 & 125.15 & 239.40 \\
\hline S.D. & 12.20 & 11.73 & 24.81 & 12.65 & 27.13 \\
\hline $\begin{array}{l}\text { ANOVA } \\
p \text {-value }\end{array}$ & & \multicolumn{4}{|c|}{$0.001 *$} \\
\hline$p_{1}$ & & 0.21 N.S. & $0.001 *$ & 0.211 & $0.001 *$ \\
\hline$p_{2}$ & & & $0.001 *$ & 0.244 & $0.001 *$ \\
\hline$p_{3}$ & & & & $0.001 *$ & 0.107 \\
\hline$p_{4}$ & & & & & $0.001 *$ \\
\hline
\end{tabular}

The difference in serum triglyceride (mean \pm SD) between controls and the four diseased groups was significant $($ Anova $=215.153, p$-value $=0.001$ ), significant difference between diseased group IIa and IIb\&IId ( $p=0.001$ for each), also significant difference in diseased group between IIb and IIc ( $p$-value $=0.001)$ and significant difference in diseased group between IIc and IId (Table 7).

Table (8): Comparison between the different studied groups regarding $\mathrm{HDL}$.

\begin{tabular}{|c|c|c|c|c|c|}
\hline HDL & $\begin{array}{l}\text { Group I } \\
" n=20 "\end{array}$ & $\begin{array}{l}\text { Group IIa } \\
\text { "n=20" }\end{array}$ & $\begin{array}{l}\text { Group IIb } \\
\text { "n=20" }\end{array}$ & $\begin{array}{l}\text { Group IIc } \\
\text { "n=20" }\end{array}$ & $\begin{array}{l}\text { Group IId } \\
" \mathrm{n}=20 "\end{array}$ \\
\hline Range & $35.0-54.0$ & $30.0-39.0$ & $30.0-40.0$ & $28.0-35.0$ & $31.0-44.0$ \\
\hline Mean & 45.95 & 34.60 & 35.55 & 31.65 & 36.85 \\
\hline S.D. & 5.87 & 2.41 & 3.76 & 2.62 & 4.31 \\
\hline ANOVA & & \multicolumn{4}{|c|}{36.483} \\
\hline$p$-value & & \multicolumn{4}{|c|}{$0.001^{*}$} \\
\hline$p_{1}$ & & $0.001^{*}$ & $0.006^{*}$ & $0.001 *$ & $0.007 *$ \\
\hline$p_{2}$ & & & 0.211 & 0.142 & 0.223 \\
\hline$p_{3}$ & & & & 0.147 & 0.211 \\
\hline$p_{4}$ & & & & & 0.311 \\
\hline
\end{tabular}

The difference in HDL (mean $\pm \mathrm{SD}$ ) between controls and the four diseased groups was significant $($ Anova $=36.483, p$-value $=0.001)$ but insignif icant difference between other diseased groups (Table 8).

Table (9): Comparison between the different studied groups regarding plasma PYY $(\mathrm{pg} / \mathrm{ml})$.

\begin{tabular}{llllll}
\hline $\begin{array}{l}\text { Plasma } \\
\text { PYY } \\
(\mathrm{pg} / \mathrm{ml})\end{array}$ & $\begin{array}{l}\text { Group I } \\
\text { "n=20” }\end{array}$ & $\begin{array}{c}\text { Group IIa } \\
\text { "n=20" }\end{array}$ & $\begin{array}{c}\text { Group IIb } \\
\text { "n=20" }\end{array}$ & $\begin{array}{c}\text { Group IIc } \\
\text { "n=20” }\end{array}$ & $\begin{array}{c}\text { Group IId } \\
\text { "n=20" }\end{array}$ \\
\hline Range & $682.0-$ & $920.0-$ & $984.0-$ & $955.0-$ & $900.0-$ \\
& 937.0 & 1204.0 & 1300.0 & 1313.0 & 1227.0 \\
Mean & 825.10 & 1072.10 & 1153.95 & 1093.25 & 1087.15 \\
S.D. & 75.98 & 103.78 & 109.22 & 105.90 & 101.73 \\
ANOVA & & & 36.483 & \\
$p$-value & & & $0.001 *$ & \\
$p_{1}$ & & $0.001 *$ & $0.001 *$ & $0.001 *$ & $0.001 *$ \\
$p_{2}$ & & & $0.046^{*}$ & 0.213 & 0.452 \\
$p_{3}$ & & & & 0.107 & 0.11 \\
$p_{4}$ & & & & & 0.652 \\
\hline
\end{tabular}

The difference in plasma PYY $(\mathrm{pg} / \mathrm{ml})$ (mean \pm SD) between controls and the four diseased groups was significant $($ Anova $=32.506, p$-value $=$ 0.001 ), but insignificant difference between other diseased groups (Table 9). 
Table (10): Comparison between the different studied groups regarding plasma ghrelin $(\mathrm{ng} / \mathrm{ml})$.

\begin{tabular}{|c|c|c|c|c|c|}
\hline $\begin{array}{l}\text { Plasma } \\
\text { ghrelin } \\
(\mathrm{ng} / \mathrm{ml})\end{array}$ & $\begin{array}{l}\text { Group I } \\
\text { "n=20" }\end{array}$ & $\underset{\text { Group IIa }}{\text { II }=20 ”}$ & $\begin{array}{l}\text { Group IIb } \\
\text { "n=20" }\end{array}$ & $\begin{array}{l}\text { Group IIc } \\
\text { "n=20" }\end{array}$ & $\begin{array}{l}\text { Group IId } \\
" n=20 "\end{array}$ \\
\hline Range & $6.0-9.0$ & $4.10-7.40$ & $4.60-7.90$ & $4.0-7.90$ & $3.90-7.20$ \\
\hline Mean & 7.56 & 5.74 & 6.37 & 6.26 & 5.80 \\
\hline S.D. & 0.89 & 0.92 & 1.20 & 1.14 & 0.98 \\
\hline $\begin{array}{l}\text { ANOVA } \\
p \text {-value }\end{array}$ & & \multicolumn{4}{|c|}{$\begin{array}{l}10.091 \\
0.001\end{array}$} \\
\hline$p_{1}$ & & $0.001 *$ & $0.001 *$ & $0.001 *$ & $0.001 *$ \\
\hline$p_{2}$ & & & $0.045^{*}$ & $0.05^{*}$ & 0.62 N.S. \\
\hline$p_{3}$ & & & & 0.25 & 0.107 N.S. \\
\hline$p_{4}$ & & & & & 0.114 N.S. \\
\hline
\end{tabular}

The difference in plasma ghrelin $(\mathrm{ng} / \mathrm{ml})$ (mean \pm SD) between controls and the four diseased groups was significant $($ Anova $=10.091, p$-value $=0.001)$, also significant differences in diseased groups between IIa and both IIb\&IIc ( $p$-value $=0.045$ and 0.05 respectively) but insignificant difference between other diseased groups (Table 10).

$p_{1}$ comparison between group I and other groups. $p_{2}$ comparison between group IIa and other groups. $p_{3}$ comparison between group IIb and other groups. $p_{4}$ comparison between group IIc and IId. $p$ was significant if $<0.05$ S.D. Standard deviation N.S. not significant.

\section{Discussion}

One third of overweight/obese persons manifest the metabolic syndrome according to ATP III diagnosis criteria [15]. In the present work, we found a negative significant correlation between plasma PYY and plasma ghrelin and a positive correlation between BMI and plasma PYY (pg/ml). Moreover, increased plasma PYY $(\mathrm{pg} / \mathrm{ml})$ in patients when compared with controls. Moreover components of metabolic syndrome were in parallel of increased plasma PYY.

\section{Importance of plasma $Y Y$ :}

Plasma PYY has many functions including retard gastric emptying and its motility, also in hibits gastric acid secretion, bile secretion, and pancreatic enzymes, and regulate food intake [16] Systemic administration of plasma PYYdecrease appetite healthy people, thus plasma PYY plays a role in regulating satiety [17]. Blood levels of plasma YY are low in fasting and increase after eating [18]. Moreoverplasma YY is also released by gastric acid, cholecystokin in (CCK), and infusion of bile acids into the ileum or colon [19]. In addition, plasma PY secretion can influenced by intestinal peristalsis and intraluminal nutrients [20]

\section{Modeofaction for peptide $Y Y$ :}

PYY acts on the arcuate nucleus of the hypothalamus by targeting the neuropeptide $Y$ neurons [21]. PYY is able to cross the blood-brain barrier freely. This indicates that there is no limit to the amount of circulating PYY that can cross that blood-brain barrier. Within the arcuate nucleus of the hypothalamus, there are two subsets of neurons that integrate signals and influence energy homeostasis. These neurons are the NPY/agouti-related peptide neurons and the pro-opiomelanocortin /cocaine- and amphetamine-regulated transcript (CART) neurons [21]. PYY has agonistic properties on Y2 receptors, so binding to those receptors leads to an inhibition of food intake [22].

Since pro-opiomelanocortin neurons are anorexigenic, this would go against the established satiating effect of neuropeptide $\mathrm{Y}$ in the body. However, it appears that PYY may more strongly inhibit neuropeptide $Y$ cells, and that the neuropeptide $\mathrm{Y}$ inhibition is strong enough to override any possible inhibition in the pro-opiomelanocortin neurons. Further evidence that pro-opiomelanocortin is not the primary regulator of neuropeptide Y-responsive satiety has been shown with reduced food intake in response to PYY3-36 administration in POMC knock-out mice [23]. Therefore, it appears that inhibition of neuropeptide $\mathrm{Y}$ via the $\mathrm{Y} 2$ receptor is the primary way in which PYY3-36 acts as an anorexigenic peptide. In the present study, there was a correlation between a ghrelin and the components of MetS.

\section{Association between ghrelin and metabolic} syndrome:

Valentine et al. [24] approved that hyperinsulinemia inhibits the activity of AMP-activated protein kinase (AMPK), and inhibition of AMPK activity because of metabolic syndrome inactivates the pentose phosphate pathway [25]. Diabetes mellitus lead to impairment of energy metabolism by increasing the production of reactive oxygen species and mitochondrial dysfunction [26] and accelerate cognitive impairment by promoting abnormal release of neurotransmitters, particularly $\gamma$-amino butyric acid [27]

There was a link between insulin and cholesterol levels. Actually, insulin increases the activity of 3-hydroxy-3-methylglutaryl-CoA reductase, which catalyzes an intermediate in cholesterol synthesis [28]. Individuals with type 2 diabetes mellitus, cholesterol absorption is decreased and its synthesis increased regardless of obesity [29]. 
Reduction in activity of tyrosine kinase, lead to insulin signaling dysfunction which an important effector system for insulin receptors, also lead to decreased activities of elements of insulin-PI3KAKT signaling, leading to elevated tau phosphorylation and decreased glucose metabolism. Particularly, apolipoprotein E, a protein responsible for the metabolism of plasma lipids [30], Moreover, apolipoprotein E s4 decreases lipid and glucose metabolism leading to dysregulation of cerebral metabolism [31]. However, duration, route, and dose administration of ghrelin control insulin and plasma glucose. For example in rats, acute (1 day) administration of ghrelin increased levels of insulin and fasting plasma glucose, but chronic (21 days) administration of ghrelin normalized these upregulations [32]. Insulin caninhibits ghrelin byupregulation of the AMPK-uncoupling protein 2 (UCP2) pathway through AMPK phosphorylation and UCP2 expression [33], transmembrane proteins (IA-20) autoantigens in hibits glucose-stimulated insulin through induction of IA-20 [34] .

Actually, ghrelin not only regulates insulin but also regulates nigrostriatal dopamine function in a UCP2-dependent manner [35]. Moreover, upregulation of UCP2 has been demonstrated to have a protective effect in animal models of ischemic stroke and Parkinson disease [30]. In elderly, middleaged people with metabolic syndromethe concentration of ghrelin is decreased compared to individuals of the same age who do not have metabolic syndrome, and its concentration rapidly is decreased as metabolic abnormalities intensify. Ghrelin participates in the metabolism of insulin and glucose. In healthy subjects, administration of acyl-ghrelin reduced insulin levels and increased glucose levels [11].

Obese children with metabolic syndrome have decreased levels of des-acyl-ghrelin and an increased acyl-ghrelin/des-acyl-ghrelin ratio compared to obese children without metabolic syndrome [36]. Additionally, obese individuals with normoglycemia and type 2 diabetes mellitus have increased plasma levels of acyl-ghrelin and decreased levels of des-acyl-ghrelin compared to lean individuals [37]. Thus, patients with metabolic syndrome and obesity have a higher acyl-ghrelin/des-acylghrelin ratio than non-obese patients with metabolic syndrome, indicating that excessive acyl-ghrelin levels may promote insulin resistance [31].

Similarly, administration of ghrelin causes changesin the activity of mitochondrial oxidative enzymein the specifictissue, and inthe expression of gene involved in lipid metabolism, and triglyc- eride content in rats, suggesting that ghrelin may be involved in the regulation of lipid distribution and metabolism [31]. Given that ghrelin-O-acyl transferase blockade decreases the acyl-ghrelin/desacyl-ghrelin/des-acyl-ghrelin ratio, administration could be a promising therapeutic approach for metabolic dysfunction [38]. It is possible that the reduce acyl-ghrelin/des-acyl-ghrelin ratio in individuals with obesity may promote insulin resistance and hyperinsulinemia [31]. Additionally, insulin transport to the brain is reduced, causing insulin deficiency. Insulin like growth factor-1 and insulin are associated with tau phosphorylation [33]

Association between PYY and ghrelin with the components of MetS. SBP in the current study is in agreement with the previous findings revealing the positive association of ghrelinwith MetS and its positive association with the components of MetS [11,38,39], further confirming the possible role of this GI hormone in metabolic syndrome, obesity and T2DM.

\section{Conclusion:}

The current study revealed the possible role GI-hormones in the pathogenesis of obesity-related metabolic disorders and MetS. There are several controversial findings in the previous literatures about the possible role of GI hormones in the pathogenesis of metabolic disorders. Elucidating the possible underlying mechanisms and confirming the results of our findings warrants further researches. There are several controversial findings in the previous literatures about the possible role of GI hormones in the pathogenesis of metabolic disorders. Elucidating the possible underlying mechanisms and confirming the results of our findings warrants further researches.

\section{References}

1- MIRINAZHAD M.M., FARHANGI M.A., JAHANGIRI L. and YAGHOUBI A.: Serum adiponectin concentrations in relation to lipid profile, anthropometric variables and insulin resistance in patients with metabolic syndrome. Mai. J. Nutr., 20 (3): 283-289, 2014.

2- ERVIN R.B.: Prevalence of metabolic syndrome among adults 20 years of age and over, by sex. age, race and ethnicity, and body mass index: United States. National Health Statistics Reports, 13: 1-8, 2009.

3- SOKHANVAR S., KHOSHI A., HAJIAGHAEI S., MOUSAVINASAB S.N. and GOLMOHAMMADI Z. Association between Apo-lipoprotein-B levels at admission of patients and short-term morbidity and mortality after myocardial infarction. J. Cardiovasc. Thorac. Res., 4 (3): 61-64, 2012.

4- AGGARWAL A., AGGARWAL S. and SHARMA V.: Cardiovascular risk factors in young patients of coronary 
artery disease: Differences over a decade. J. Cardiovasc. Thorac. Res., 6 (3): 169-173, 2014.

5- ZWIRSKA-KORCZALA K., KONTUREK S.J., SODOWSKI M., WYLEZOL M., KUKA D., SOWA P., ADAMCZYK-SOWA M., KUKLA M., BERDOWSKA A., REHFELD J.F., BIELANSKI W. and BRZOZOWSKI T.: Basal and Postprandial Plasma Levels of Pyy, Ghrelin. J. Physiol. Pharmacol., 58 (1): 13-35, 2007.

6- BAITERHAM R.L., COHEN M.A. and ELLIS S.M.: Inhibition of food intake in obese subjects by peptide YY3-36. NEJM, 349: 941-948, 2003.

7- KOJIMA M., HOSODA H., DATE Y., NAKAZATO M., MATSUO H. and KANGAWA K.: Ghrelin is a growthhormone-releasing acylated peptide from stomach. Nature, 402: 656-660, 1999.

8- NAKAZATO M., MURAKAMI N., DATE Y., KOJIMA M., MATSUO H., KANGAWA K. and MATSUKURA S.: A role for ghrelin in the central regulation of feeding. Nature, 409: 194-198, 2001.

9- CUMMINGS D.E.: Ghrelin and the short- and longregulation of appetite and body weight. Physiol. Behavior, 89: 71-84, 2006.

10- SHIH P.B., WANG L., CHIRON S., WEN G., NIEVERGELT C., MAHATA M., KHANDRIKA S., RAO F., FUNG M.M., MAHATA S.K., HAMILTON B.A. and O'CONNOR D.T.: Peptide YY (PYY): Gene polymorphisms in the 3'-untranslated and proximal promoter regions regulate cellular gene expression and PYY secretion and metabolic syndrome traits in vivo. J. Clin. Endocrinol. Metab., 94 (11): 4557-4566, 2009.

11-MORA M., ADAM V., PALOMERA E., BLESA S., DIAZ G., BUQUET X., SERRA-PRAT M., MARTINESCUDERO J.C., PALANCA A., CHAVES J.F. and PUIG-DOMINGO M.: Matard Aging Study Group: Ghrelin gene variants influence on metabolic syndrome components in aged Spanish population. PloS One, 10 (9): e0136931, 2015.

12- GRUNDY S.M., HANSEN B. and SMITH S.C.: Clinical management of metabolic syndrome: Report of the American Heart Association/National Heart. Lung, and Blood Institute American Diabetes Association conference on scientific Issues related to management. Circulation, 109: 551-556, 2004.

13- WILLETT W.C., DIETZ W.H. and COLDITZ G.A.: Guidelines for healthy weight. N. Engl. J. Med., 341: 427-34, 1999.

14-KAUR J.: A comprehensive review on metabolic syndrome. Cardiology Research and Practice, 14: 962-66, 2014.

15- FORD E.S., GILES W.H. and DIETZ W.H.: Prevalence of the metabolic syndrome among US adults: Find ings from the third National Health and Nutrition Examination Survey. JAMA, 287: 356-359, 2002.

16- MALJAARS P.W., PETERS H.P. and MELA D.J.: Ileal brake: A sensible food target for appetite control. A review. Physiol. Behav., 95: 271-281, 2008.

17- KARRA E., CHANDARANA K. and BATTERHAM R.L.: The role of peptide YY in appetite regulation and obesity. J. Physiol., 587: 19-25, 2009.

18- DRUCE M.R., SMALL C.J. and BLOOM S.R.: Minireview: Gut peptides regulating satiety. Endocrinology, 145: 2660-2665, 2004.
19- KO B.S., HAN J.H. and JEONG J.I.: Mechanism of action of cholecystokinin on colonic motility in isolated, vascularly perfused rat colon. J. Neurogastroenterol. Motil., 17: 73-81, 2011.

20- DEGEN L., DREWE J. and PICCOLI F.: Effect of CCK1 receptor blockade on ghrelin and PYY secretion in men. Am. J. Physiol. Regul. Integr. Comp. Physiol., 292: 13911399, 2007.

21- SUZUKI K., SIMPSON K.A., MINNION J.S., et al.: The role of gut hormones and the hypothalamus in appetite regulation. Endocr. J., 57: 359-372, 2010.

22- BATTERHAM R.L. and BLOOM S.R.: The gut hormone peptide YY regulates appetite. Ann. N Y Acad. Sci., 994: 162-168, 2003.

23- CHALLIS B.G., COLL A.P. and YEO G.S.: Mice lacking pro-opiomelanocortin are sensitive to high-fat feeding but respond normally to the acute anorectic effects of pep- tide-YY(3-36): Proc. Natl. Acad. Sci. USA, 101: 4695-4700, 2004.

24- VALENTINE R.J., COUGHLAN K.A., RUDERMAN N.B. and SAHA A.K.: Insulin inhibits AMPK activity and phosphorylates AMPK Ser(4):(8):(5):/(4):(9):(1): Through Akt in hepatocytes, myotubes and incubated rat skeletal muscle. Arch. Biochem. Biophys, 562: 62-69, 2014

25- SAITO Y., CHAPPLE R.H., LIN A., KITANO A. and NAKADA D.: AMPK protects leukemia-initiating cells in myeloid leukemias from metabolic stress in the bone marrow. Cell. Stem. Cell., 17: 585-596, 2015.

26- BONOMINI F., RODELLA F.L. and REZZANI R.: Metabolic syndrome, aging and involvement of oxidative stress. Aging Dis., 6: 109-120, 2015.

27- VAN BUSSEL F.C., BACKES W.H., HOFMAN P.A., PUTS N.A., EDDEN R.A. and VAN BOXTEL M.P.: Increased GABA concentrations in type 2 diabetes mellitus are related to lower cognitive functioning. Medicine, 95: 4803-7, 2016

28- NELSON T.J. and ALKON D.L.: Insulin and cholesterol pathways in neuronal function, memory and neurodegeneration. Biochem. Soc. Trans., 33: 1033-1036, 2005.

29- SIMONEN P.P., GYLLING H.K. and MIETTINEN T.A.: Diabetes contributes to cholesterol metabolism regardless of obesity. Diabetes Care, 25: 1511-1515, 2002.

30- LIU Y., LIU F., GRUNDKE-IQBAL I., IQBAL K. and GONG C.X.: Deficient brain insulin signalling pathway in Alzheimer's disease and diabetes. J. Pathol., 225: 5462, 2011.

31- BARAZZONI R., ZANETTI M., CATTIN M.R., VISINTIN L., VINCI P. and CATTIN L.: Ghrelin enhances in vivo skeletal muscle but not liver AKT signaling in rats. Obesity, 15: 2614-2623, 2007a.

32- GOSHADROU F., KAZEROUNI F., MEHRANFARD N. and SADEGHI B.: Chronic administration of ghrelin regulates plasma glucose and normalizes insulin levels following fasting hyperglycemia and hyperinsulinemia. Gen. Comp. Endocrinol., 224: 113-120, 2015.

33- WANG Y., NISHI M., DOI A., SHONO T., FURUKAWA Y. and SHIMADA T.: Ghrelin inhibits insulin secretion through the AMPK-UCP2 pathway in beta cells. FEBS Lett., 584: 1503-1508, 2010. 
34- DOI A., SHONO T., NISHI M., FURUTA H., SASAKI H. and NANJO K.: IA-2beta, but not IA-2, is induced by ghrelin and inhibits glucose-stimulated insulin secretion. Proc. Natl. Acad. Sci. USA, 103: 885-890, 2006.

35- ANDREWS Z.B., ERION D., BEILER R., LIU Z.W., ABIZAID A. and ZIGMAN J.: Ghrelin promotes and protects nigrostriatal dopamine function via a UCP2dependent mitochondrial mechanism. J. Neurosci., 29: 14057-14065, 2009.

36- FARHANGI M.A., JAHANGIRY L., MIRINAZHAD M.M., SHOJAEEZADE D., MONTAZERI A. and YAGHOUBI A.: A web-based interactive lifestyle modification program improves lipid profile and serum adiponectin concentrations in patients with metabolic syn- drome: The "Red Ruby" study. Int. J. Diab. Develop. Ctrs., 37 (1): 21-30, 2017.

37- FORD H.E., PETERS V. and MARTIN N.M.: Effects of oral ingestion of sucralose on gut hormone response and appetite in healthy normal-weight subjects. Eur. J. Clin. Nutr., 65: 508-513, 2011.

38- PULKKINEN L, UKKOLA O., KOLEHMAINEN M. and UUSITUPA M.: Ghrelin in diabetes and metabolic syndrome. Int. J. Peptid., 24: 1-11, 2010.

39- BRANDON J.A., FARMER B.C., WILLIAMS H.C. and JOHNSON L.A.: APOE and Alzheimer's disease: Neuroimaging of metabolic and cerebrovascular dysfunction. Front Aging Neurosci., 10: 180-186, 2018.

\section{العلاقة بين تركيز ببتيدات الأمعاء (بولى ببتيديى والجريلين)

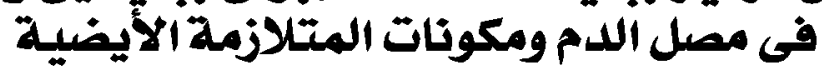 فى المرضى الذكور الهصريين}

خلفية البحث: خلال العقدين الماضيين، حدثت زيادة ملحوظة في عدد الأثخاص المصابين بمتلازمة التمثيل الغذائى في جميع أنحاء

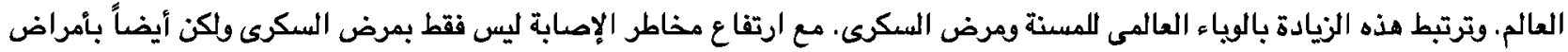

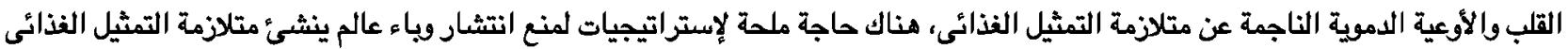

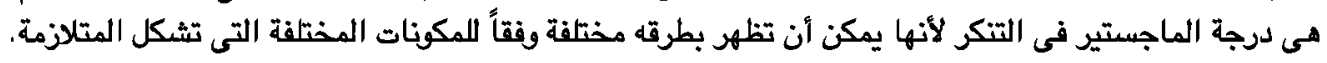

الهدف من الدراسة: هو تقدير مستويات البلازما الصيامية للبولى بيتيديى والجريلين فى متلازمة التمثيل الغذائى الخالية من الدهون مقارنة مع المرضى الذين يعانوف من زيادة التمثيل الغذائى.

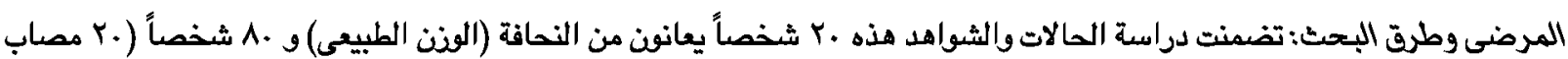

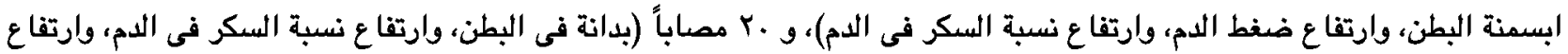

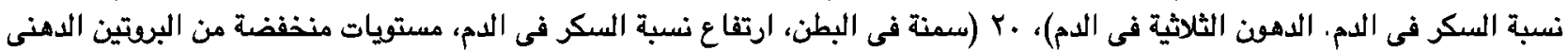

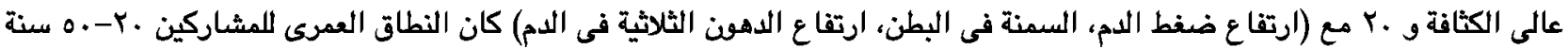
وتم قياس الخصائص الأنثروبرمترية المشارعين.

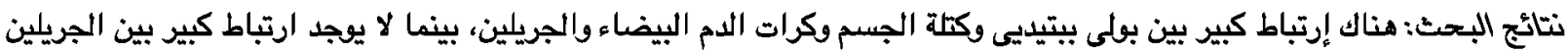

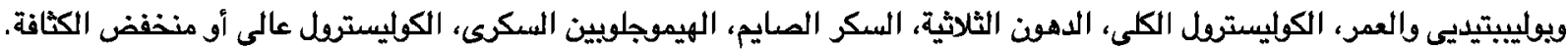

الإستتّاج: كثفت الدراسة الحالية عن الدود المحتمل للعديد من هرمونات الجهاز الهضمى فى التسبب فى الأمراض المصاحبة للسمنة

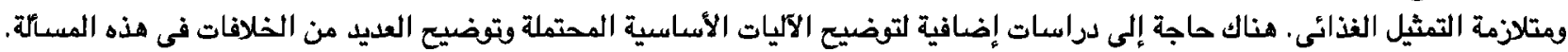

